\title{
An Analysis of Renewable Water Sources in Saudi Arabia
}

\author{
Nashmi H. Alrasheedi \\ Mechanical Engineering Department, Al Imam Mohammad Ibn Saud Islamic University (IMSIU), \\ Riyadh, Saudi Arabia \\ Email: nhrasheedi@imamu.edu.sa
}

Received 17 September 2014; revised 12 October 2014; accepted 8 November 2014

Copyright (C) 2014 by author and Scientific Research Publishing Inc.

This work is licensed under the Creative Commons Attribution International License (CC BY). http://creativecommons.org/licenses/by/4.0/

(c) (i) Open Access

\begin{abstract}
Kingdom of Saudi Arabia (KSA) is located in a very harsh natural desert environment with no rivers or lakes and an average yearly rainfall of less than $100 \mathrm{~mm}$. The country is under extreme water shortage conditions. KSA utilizes conventional (natural) and unconventional water resources to satisfy the ever increasing water demand. The purpose of this paper is to analyze two approaches to obtaining fresh water from renewable water resources, namely they are seawater distillation using solar energy and gathering liquid water from fog. In order to conduct the study for seawater distillation a solar still basin has been designed, manufactured and tested in selected day for saline water in month of April, 2012. The solar still consists of insulated metal box with channels. Pyramidal glass covers attached to the basin at an angle $\left(=45^{\circ}\right)$, and the basin area of the still is $0.25 \mathrm{~m}^{2}$ and filled with 6 liters of seawater. The average daily output was found to be 3.924 liters/day. Further, to harvesting water from fog a Standard Fog Collector (SFC) was designed and manufactured in Asir region with locally available materials and imported mesh. This SFC was installed in April 2012. The site was chosen based on topography and altitude and data from April 2012 to March 2013 were obtained. Measurements with the SFC were made for region with 3200 $m$ elevation. The results indicate that the average water production was $6.225 \mathrm{~L} /\left(\mathrm{m}^{2} \cdot\right.$ day $)$ over the studied period and the highest average water production was recorded in December 11.20 $\mathrm{L} /\left(\mathrm{m}^{2} \cdot\right.$ day $)$. The highest water collection was $20 \mathrm{~L} /\left(\mathrm{m}^{2} \cdot\right.$ day $)$ and recorded in Jan. 05,2013 at Rayda site, and furthermore for the same site, the best average water production of 10.52 $\mathrm{L} /\left(\mathrm{m}^{2} \cdot\right.$ day) was obtained in winter three months period namely (December, November and January).
\end{abstract}

\section{Keywords}

Renewable, Energy, Solar, Basin, Resources, Distillation, Fog, Collector 


\section{Introduction}

The Kingdom of Saudi Arabia (KSA) is located in a very harsh natural desert environment with no rivers or lakes and an average yearly rainfall of less than $100 \mathrm{~mm}$. The country is under extreme water shortage conditions. To meet the ever increasing water demand, KSA currently produces around 1 billion cubic meter of desalinated sea water per year. KSA utilizes conventional (natural) and unconventional water resources to satisfy the ever increasing water demand in Figure 1.

KSA utilizes conventional (natural) and unconventional water resources to satisfy the ever increasing water demand. The conventional water resources include surface water and groundwater. Surface water consists of seasonal runoff flowing valleys during the months of November and April [1]. The runoff water range from 2 to 2.4 billion cubic meter (billion $\mathrm{m}^{3}$ ) per year mostly exists in the southwest and coastal area where rainfall is reasonably abundant. Runoff water is captured in 260 dams collecting an estimated 0.6 billion $\mathrm{m}^{3}$ per year [2].

Indeed, one of the important and technically viable applications of solar energy is the distillation of seawater coastal areas and small islands, and brackish wells water in remote towns and villages. Such utilization of solar energy offers an almost cost-free alternative for supplying potable water, particularly for small communities in arid regions [3], which are characterized by low demand of water and abundant solar radiation. This advantage is generally offset by the low productivity of commonly used solar stills. An early large-scale solar still was built in 1872 to supply a mining community in Chile with drinking water [4]. Therefore, extensive efforts have been carried out through numerous investigations to improve the efficiency of solar distillation process. Various approaches have been suggested to achieve such goal, either through improving designs of conventional stills, or developing unique designs through adjustment of stills operating parameters [5].

Furthermore, where no conventional water resources are available, there is a chance of obtaining fresh water from fog. Fog harvesting has been investigated for more than thirty years. The well-known fog water collection systems erected successfully in the mountainous coastal areas of Chile, clearly indicated the water harvesting potential of fog as reported in [6]. Fog water collection systems have been implemented in Saudi Arabia during the period 2012 to 2013 and the results indicate that at highest altitudes (at Alsooda), it is feasible to obtain an average water production of $6.225 \mathrm{~L} /\left(\mathrm{m}^{2} \cdot\right.$ day) over the studied period [7].

\section{Water Distillation by Single Solar Basin}

The single basin stills have been much studied and their behavior is well understood. They remain the only design proven in this field. Efficiencies of $25 \%$ are typical [8]. The basic solar still consists of a deep basin, lined with a black waterproof material to hold the water to a depth of $5-20 \mathrm{~cm}$ and a cover, which is transparent to solar radiations [9]. The solar radiations transmitted by the cover are absorbed by the basin liner, which

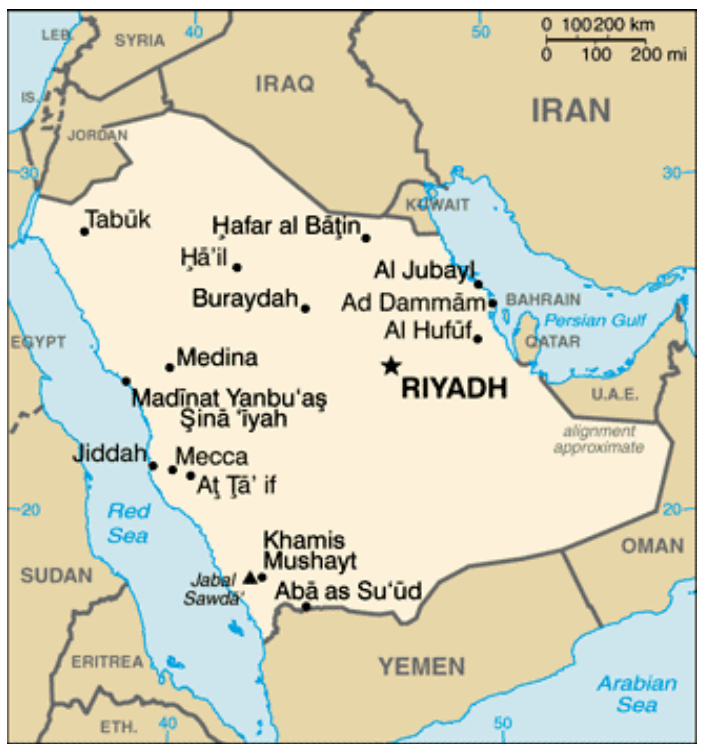

Figure 1. Saudi Arabia. 
increases the water temperature and vapor pressure. The water vaporizes and loses heat to the cover by evaporation, convection and radiation, and by conduction to the base and walls of the solar still. The vaporized water is condensed along the cover material transferring the heat of condensation to the ambient air and flows down to the bottom of sloped cover and is collected in the water channel for use. The water can be fed continuously or it could be intermittent but the quantity of water in the basin should be twice the fresh water produced daily. Total daily output of the solar still decreases with increasing water depth, but overnight output increases with an increase in water depth, which contributes considerably towards the total daily output.

\subsection{Design of Solar Still}

A schematic diagram of the designed solar still is shown in Figure 2. The actually fabricated solar still is shown also in Figure 3. The basin area of the still is $0.25 \mathrm{~m}^{3}$, fabricated using galvanized iron sheet of 18 gauge thickness. The bottom and sides of the basin are insulated by $5 \mathrm{~cm}$ thick fiber-glass surrounded by a wooden frame of $5 \mathrm{~cm}$ thickness. The surface of the basin is painted black to absorb maximum solar radiations.

On the inside rim of the basin two troughs have been fixed with each one extends along two sides of the basin. The main function of these troughs is to collect the distillated water falling from the glass cover which is fixed above the tray. Each trough is titled at a small to permit the distillated water to leave the stiller through water to a graded flask. The function of the glass cover is to permit solar radiation to pass to the stiller and elevate the temperature of the hot water in the tray. This enhances the evaporation process of water in the basin, which will condense on the inner surface of the glass covers whose temperature is definitely lower than that of the water.

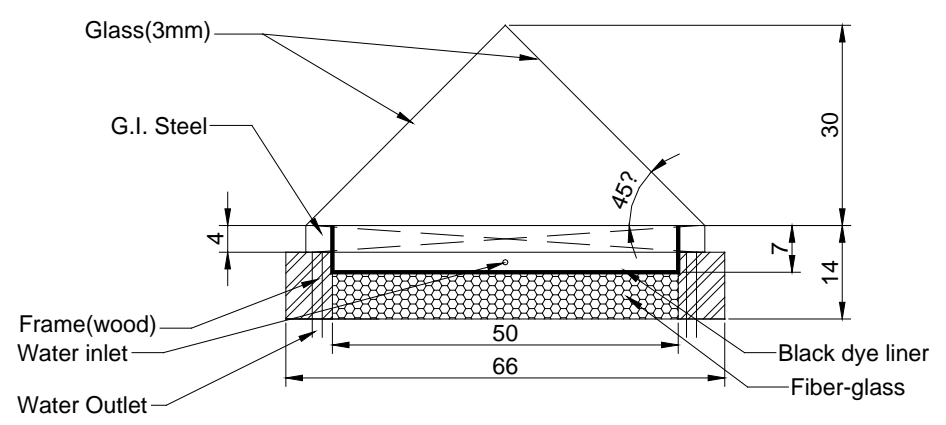

Note: All dimension in $\mathrm{cm}$.

Figure 2. Schematic diagram of the designed single basin solar still (drawn not to scale).

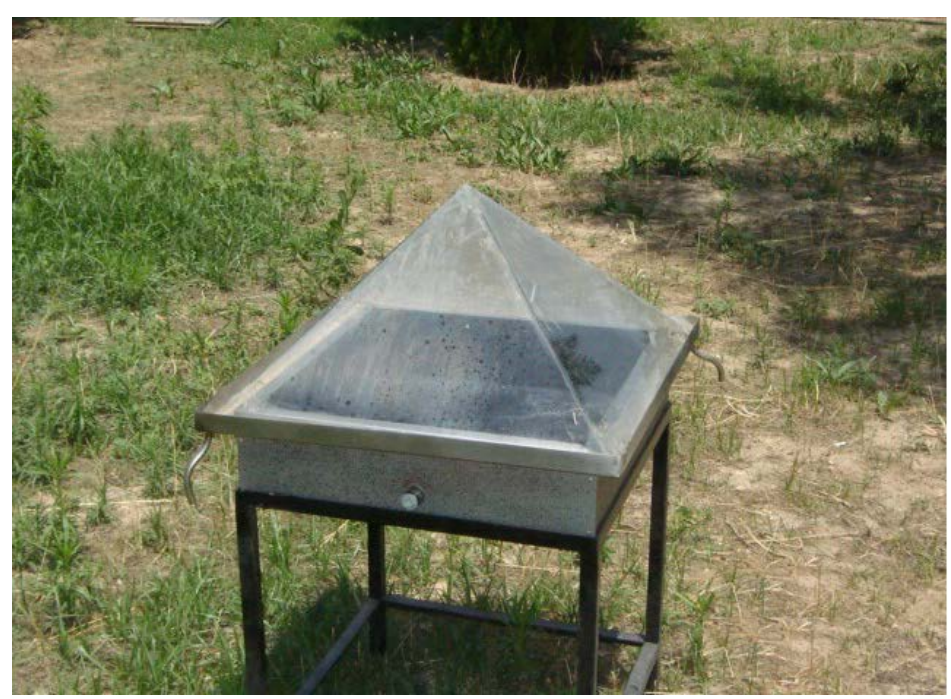

Figure 3. The fabricated solar still being tested in outdoor conditions. 
Four glass covers are used on the four sides of the tray. Each side is equilateral triangle. The four sides when assembled and contained in frame pyramid shape of the stiller as shown in Figure 2. To evaluate the performance of the water distillation process, the ambient temperature is measured along with the hourly solar radiation and the amount of distillate. All measured parameters are recorded every hour starting from 6 a.m. to 5 p.m. daily.

\subsection{Measurements and Results}

Investigation of the proposed still performance was carried out through measurements of different parameters for solar still contains water. The amount of water was 6 liters and the solar still was tested outdoors at Alsooda in Assir region. The measured parameters concerning the distillation process are the hourly distillated quantity of water. Also the ambient conditions of solar insulation and ambient temperature were recorded every hour over the day-light during the period of performance tests. The wind speed has been determined from the recorded official weather data for Abha city. All these measured parameters have been used to evaluate the performance of the studied still. The obtained results are presented and discussed below.

Table 1 includes the measured hourly values of ambient temperature, amount of distillated water produced from the still, and solar radiation and wind speed on May 14, 2012.

Figure 4 shows the variation of the hourly productivity (amount of distillated water) along the day of May 14, 2012 for the tested still.

The figure indicates that the rate of hourly productivity for the still increased with time until reaching a maximum value near noon time. In the afternoon period, the hourly distillation rate decreases until reaching its lowest value at sunset hour. The distillation process continued during the night because of the heat in the water, however the amount produced was very low. No measurements were taken of productivity during the night, only the accumulated quantity was recorded in the morning of the next day.

\section{Extraction of Water from the Fog}

The potential for fog collection in Saudi Arabia was investigated using Standard Fog Collector (SFC). The SFC is made of a $1 \mathrm{~m}^{2}$, double-layer, and 35\% shade coefficient polypropylene mesh and stands $2 \mathrm{~m}$ above the ground supported by a post at either end or arranged perpendicular to the direction of the prevailing wind.

Basically, as water collects on the net, the droplets join together to form larger drops that fall under the influence of gravity into a gutter at the bottom of the panel, from which it is conveyed to a storage tank. The collector itself is completely passive, and the water is conveyed to the storage system by gravity. To protect the SFC from cows and chimpanzees living in the area of the sites, the SFC was guarded by metal nets with $1.75 \mathrm{~m}$ high from the ground as seen in Figure 5.

Table 1. Ambient temperature, distillated water, solar radiation and wind speed as function of time (on May 14, 2012).

\begin{tabular}{ccccc}
\hline Time $(\mathrm{h})$ & Ambient temperature $\left(\mathrm{T},{ }^{\circ} \mathrm{C}\right)$ & Amount of destillated water $\left(\mathrm{cm}^{3}\right)$ & Solar radiation $\left(\mathrm{kw} / \mathrm{m}^{2}\right)$ & Wind speed $(\mathrm{km} / \mathrm{h})$ \\
\hline 6 & 10.2 & 22 & 0.01 & 8.5 \\
7 & 18.6 & 26 & 0.69 & 9.3 \\
8 & 21.8 & 29 & 1.11 & 9.52 \\
9 & 21.9 & 45 & 1.53 & 9.66 \\
10 & 24.2 & 62 & 1.73 & 9.69 \\
11 & 22.8 & 96 & 1.82 & 9.72 \\
12 & 22.3 & 130 & 1.69 & 9.8 \\
13 & 22.4 & 152 & 1.31 & 10 \\
14 & 20.2 & 132 & 0.86 & 10.3 \\
15 & 19 & 105 & 0.10 & 10.55 \\
17 & 16.5 & 88 & 0.08 & 10.75 \\
\hline
\end{tabular}

Note: Saline water from red sea has been used for this day. 


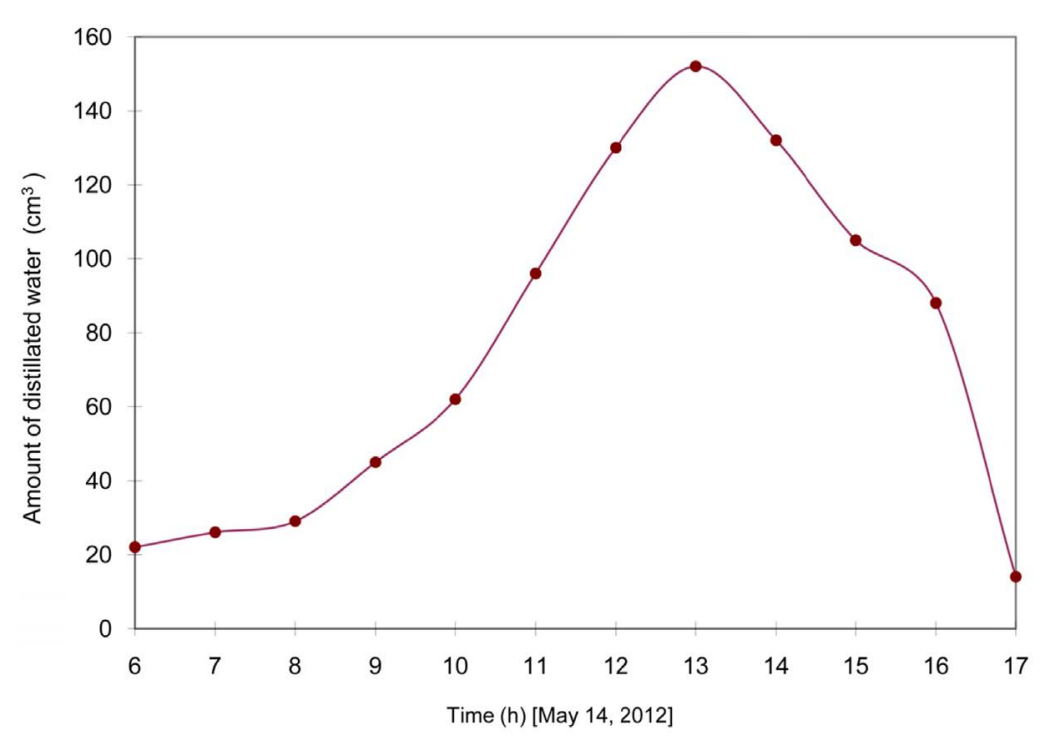

Figure 4. The variation of the hourly productivity (amount of distillated water) along the day of May 14, 2012 for the studied still.

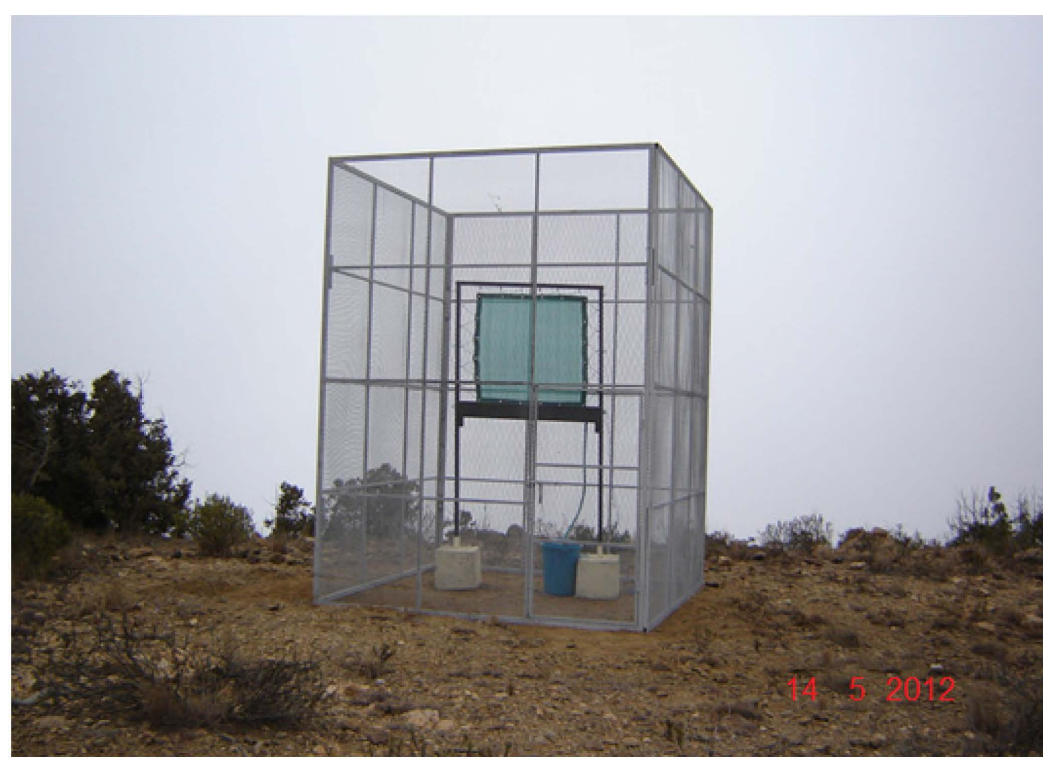

Figure 5. Fog water collection system (SFC) at Al-sooda, Assir region, Saudi Arabia.

\section{Fog Collection Rates}

The freshwater from fog has been collected daily morning by a $50 \mathrm{~L}$ plastic scale of measurement over twelve month's period, so that the measurements were accurate. The results of experiments with SFCs from April 2012 to March 2013 at the Rayda Serve site in Assir region indicates a seasonal variation in fog frequency with most fog occurring from November to February (Table 2). The data were collected and recorded daily over the studied period.

The results indicate that the average water production of $6.225 \mathrm{~L} /\left(\mathrm{m}^{2}\right.$.day) over the studied period and in the highest average water production was recorded in December $11.20 \mathrm{~L} /\left(\mathrm{m}^{2} \cdot\right.$ day $)$. The highest water collection was $20 \mathrm{~L} /\left(\mathrm{m}^{2}\right.$.day) and recorded in Jan. 05, 2013 at Rayda site, and furthermore for the same site, the best average water production of $10.52 \mathrm{~L} /\left(\mathrm{m}^{2}\right.$.day) was obtained in winter three months period namely (December, November and January). 
Table 2. Average water production recorded from fog of the Rayda site for each month over the studied period.

\begin{tabular}{cc|}
\hline Time period (month) & Average water production collected from fog $\mathrm{L} /\left(\mathrm{m}^{2} \cdot\right.$ day $)$ \\
\hline April 2012 & 4.5 \\
May 2012 & 2.95 \\
June 2012 & 2.0 \\
July 2012 & 2.25 \\
August 2012 & 3.25 \\
September 2012 & 4.75 \\
October 2012 & 7.15 \\
November 2012 & 9.85 \\
December 2012 & 11.20 \\
January 2013 & 10.50 \\
February 2013 & 9.15 \\
March 2013 & 7.15 \\
\hline
\end{tabular}

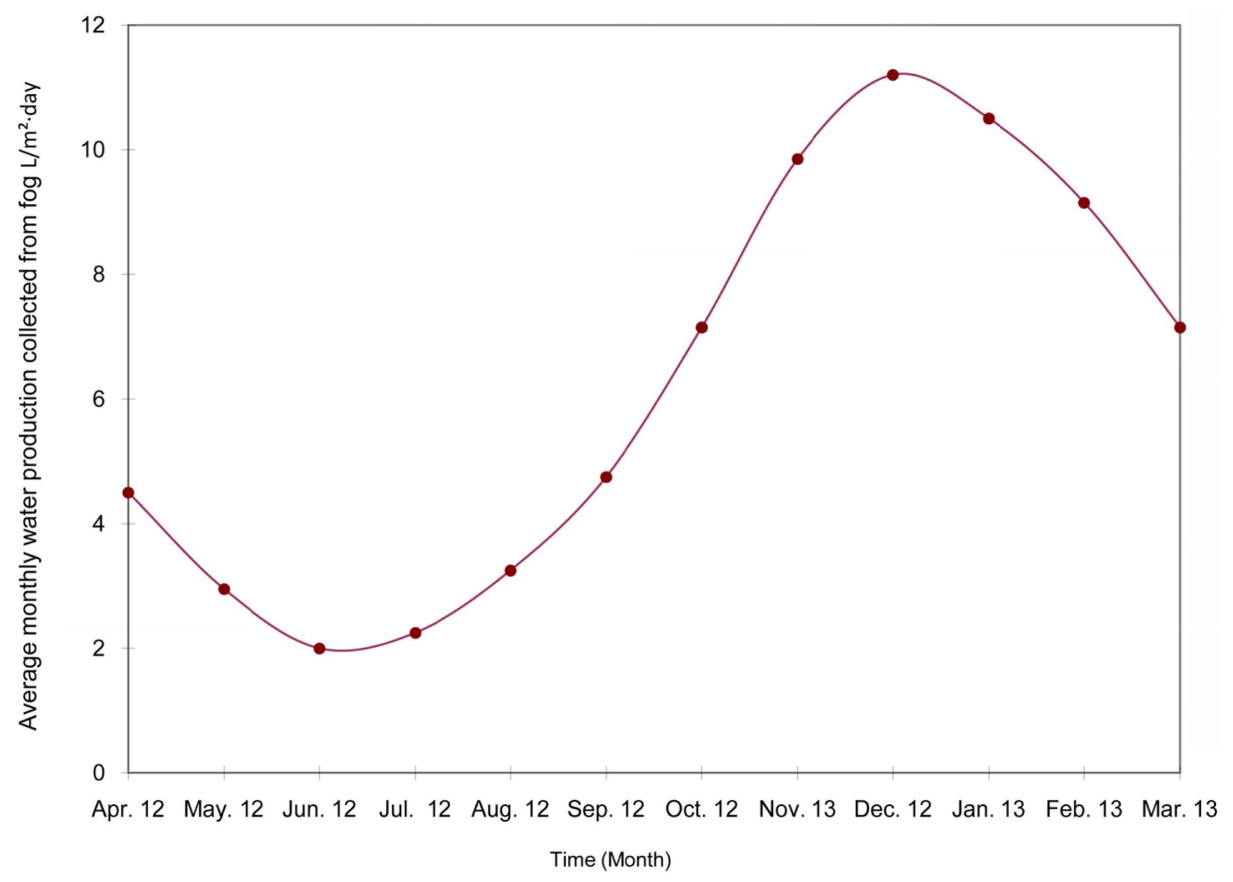

Figure 6. Average monthly water collected from fog of studied period.

The average water amount of fog collection for each month during the experiments period is demonstrated in Figure 6. The field data pointed out the fog water collection potential in Asir region. The rates are encouraging, especially for Rayda serve site during the winter months (November, December, January and February).

The collection rates are high for sites elevations of approximately $3000 \mathrm{~m}$ or more above sea level such in AlSooda region where the collector is located.

\section{Conclusions}

Two approaches to obtaining fresh water from renewable water resources were analyzed. They are seawater dis- 
tillation using solar energy and harvesting of liquid water from fog. A single basin solar still was fabricated and tested in Assir region, Saudi Arabia. The average daily output was found to be 3.924 liters/day. The cost effective design is expected to provide the rural communities an efficient way to convert the seawater and brackish water into potable water.

Standard Fog Collector (SFC) was also designed, manufactured and tested in Assir region with locally available materials and imported mesh. The promising results from the studied site in Rayda serve represent opportunities to obtain a new water resource to supply freshwater to water-poor communities in Assir region. The best collection took place at altitudes higher than $3000 \mathrm{~m}$. It was indicated that the origin of the fog, wind speed during fog events and elevation are major determinants in the volume of water that can be collected, so selection of a suitable site is vital to the success of a fog water harvesting project. The results indicate that an average water production is $6.225 \mathrm{~L} / \mathrm{m}^{2}$ day over the studied period. The highest water collection rate was $20 \mathrm{~L} / \mathrm{m}^{2}$ day recorded in Jan. 05, 2013 furthermore the best average water production of $10.52 \mathrm{~L} / \mathrm{m}^{2}$ day was obtained in winter 3 months period namely (December, November and January).

\section{References}

[1] Akasakal, A. (1998) Rainfall Amount in Saudi Arabia and a Technique to Increase the Rainfall by Cloud Seeding. Arabian Journal for Science and Engineering, 23, 101-119.

[2] Abdullah, M.A. and Al-Mazroui, M.A. (1998) Climatological Study of the Southwestern Region of Saudi Arabia. I. Rainfall Analysis. Climate Research, 9, 213-233. http://dx.doi.org/10.3354/cr009213

[3] Al-Hassan, G. and Algarni, S. (2013) Exploring of Water Distillation by Single Solar Still Basins. American Journal of Climate Change, 2, 57-61. http://dx.doi.org/10.4236/ajcc.2013.21006

[4] Intermediate Technology Development Group. Solar Distillation: Technical Brief. The Schumacher Centre for Technology \& Development, Rugby. http://www.itdg.org/docs/technical_information_service/solar_distillation.pdf

[5] S. Aboul-Enein, El-Sebaii, A.A. and El-Bialy, E. (1998) Investigation of a Single-Basin Solar Still with Deep Basins. Renewable Energy, 14, 299-305. http://dx.doi.org/10.1016/S0960-1481(98)00081-0

[6] Schemenauer, R.S. and Cereceda, P. (1992) The Quality of Fog Water Collected for Domestic and Agricultural Use in Chile. Journal of Applied Meteorology, 31, 275-290.

[7] Al-Hassan, G. (2009) Fog Water Collection Evaluation in Asir Region-Saudi Arabia. Water Resource Management, 23, 2805-2813. http://dx.doi.org/10.1175/1520-0450(1992)031<0275:TQOFWC>2.0.CO;2

[8] Lindblom, J. (2010) Solar Thermal Technologies for Seawater Desalination: State of the Art. Lulea University of Technology, Lulea. http://energi.fysikk.uio.no/rebus/phd 2003/SOASeawater

[9] Harris Norman, C., Miller Cydney, E. and Thomas Irving, E. (1985) Solar Energy Systems Design. Wiley, New York. 
Scientific Research Publishing (SCIRP) is one of the largest Open Access journal publishers. It is currently publishing more than 200 open access, online, peer-reviewed journals covering a wide range of academic disciplines. SCIRP serves the worldwide academic communities and contributes to the progress and application of science with its publication.

Other selected journals from SCIRP are listed as below. Submit your manuscript to us via either submit@scirp.org or Online Submission Portal.
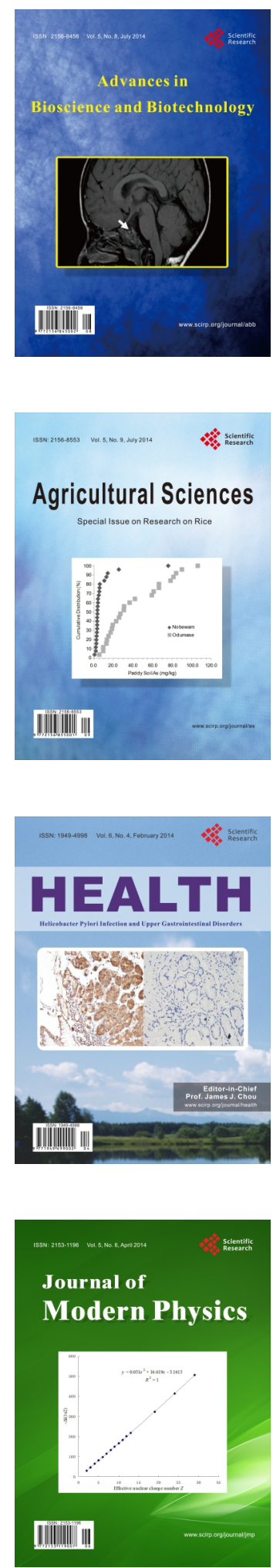
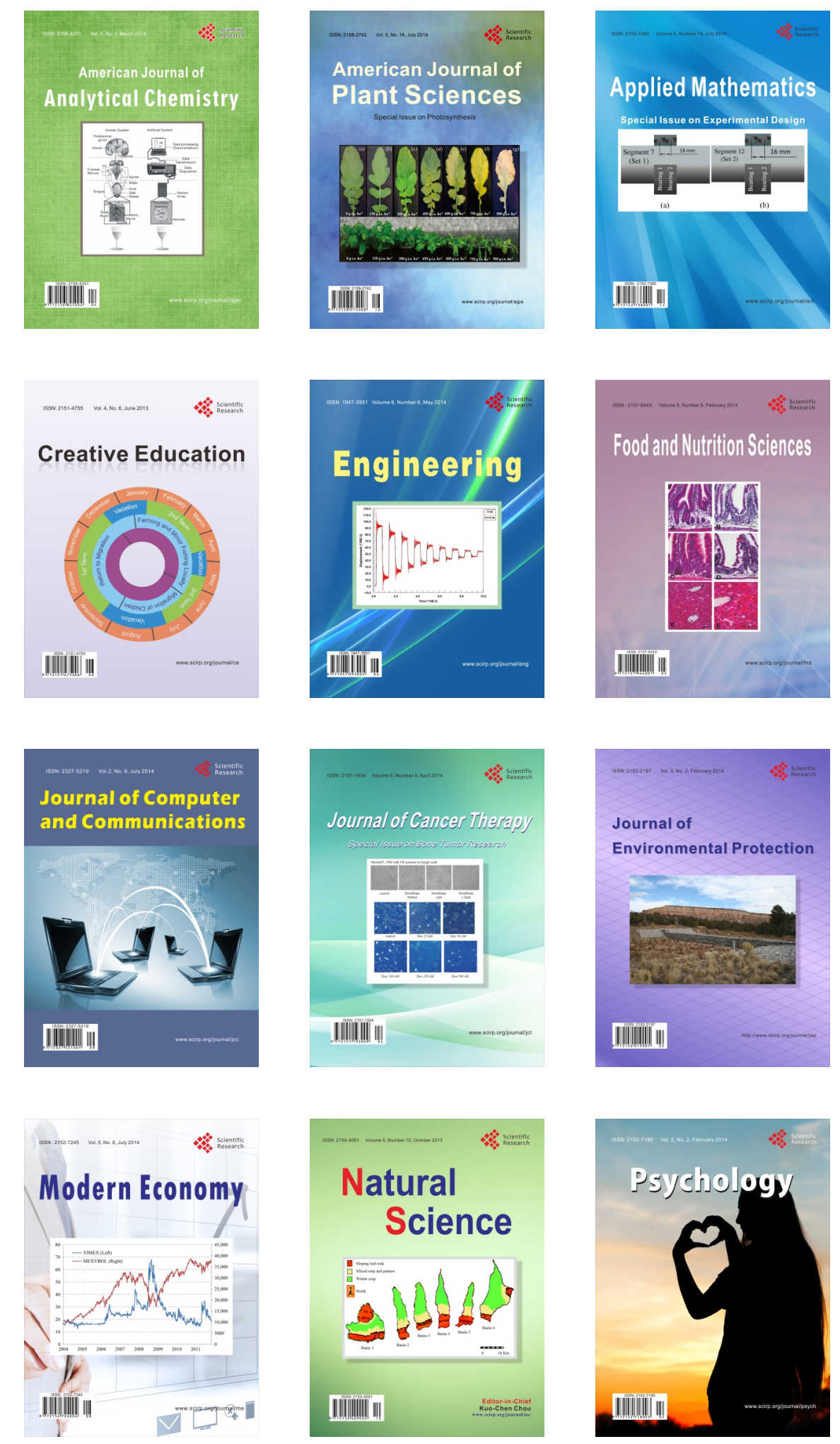